\title{
Intraocular Acrylic Allergy: Is it Something to Sneeze at?
}

Majid Moshirfar (D) - Nour Bundogji · Alyson N. Tukan •

Rachel Huynh

Received: May 28, 2021 / Accepted: July 1, 2021 / Published online: July 14, 2021

(C) The Author(s) 2021

\section{ABSTRACT}

Cataract surgery is most commonly performed with acrylic intraocular lens (IOL) implantation. To date, there have been no reported cases of intraocular acrylic allergy despite increasing rates of acrylic-induced contact dermatitis elsewhere in the body. Concern regarding acrylate sensitization is gaining traction in the ophthalmology community. This commentary explores the lack of intraocular atopy and whether an acrylic allergy necessitates extensive preoperative consideration.

M. Moshirfar ( $\square)$

Hoopes Vision Research Center, Hoopes Vision, 11820 S. State St., Ste.200, Draper, UT 84020, USA e-mail: cornea2020@me.com

\section{Moshirfar}

John A. Moran Eye Center, University of Utah

School of Medicine, Salt Lake City, UT, USA

M. Moshirfar

Utah Lions Eye Bank, Murray, UT, USA

N. Bundogji · A. N. Tukan

University of Arizona College of Medicine Phoenix, Phoenix, AZ, USA

R. Huynh

University of Utah School of Medicine, Salt Lake

City, UT, USA
Keywords: Acrylates; Acrylic; Biocompatibility; Contact dermatitis; Intraocular lens; Patch testing

\section{Key Summary Points}

Acrylic intraocular lenses (IOL) are the most commonly utilized material in phacoemulsive cataract surgery with no reports of intraocular acrylic sensitization.

As a result of the increasing prevalence of acrylic allergies, the question arises whether acrylic IOLs will continue to be well tolerated.

In patients who are highly concerned, patch testing and non-acrylic IOL options are available, though routine allergy testing is not indicated.

Patients can be reassured that acrylic IOLs continue to be safe as evidence suggests these lenses are biologically inert.

Intraocular lens (IOL) implantation restores vision by using a synthetic material to replace the clouded native lens. Dr. Harold Ridley pioneered the first IOL placement in 1949 with a poly(methyl methacrylate) (PMMA) lens, which was observed to be biocompatible in war 
veterans exposed to ocular shrapnel. At that time, there was concern for post-implantation precipitation [1, 2], prompting Dr. Benedetto Strampelli to preventatively "humanize" the IOL in patients' earlobes in an effort to minimize intraocular inflammation [3]. Frederick Ridley's sodium hydroxide sterilization method was universally used starting in 1957 until the US Food and Drug Administration mandated the use of ethylene oxide in 1978 [3]. While IOL sterilization has effectively been achieved in today's world of cataract surgery, there is now a concern of sensitization to lens implants. Given the rising prevalence of acrylic allergies [4], the question arises whether acrylic IOLs will continue to be well tolerated.

Acrylics are a notorious allergen elsewhere in the body, causing a delayed type IV hypersensitivity reaction to the monomer and oligomers. Acrylates, (meth)acrylates, and cyanoacrylates polymerize into synthetic thermoplastic resins ubiquitous in medical devices, dentistry, and the beauty and printing industries. Over the past decade, acrylic monomers have been shown to cause sensitization and allergic contact dermatitis in both occupational and nonoccupational settings [5]. The first report of an acrylic allergy was by Stevenson in 1941 [6]. Since then, there have been numerous cases of methyl (meth)acrylate (MMA) allergies from various sources [7-11], including electrocardiogram hydrogel and artificial nails [12]. Although the prevalence of acrylic allergy in the general population is unknown, one study observed a prevalence of $1.0-1.4 \%$ in a patch-tested population in Sweden and Singapore [13]. Despite minimal understanding of an exact sensitization rate, (meth)acrylates were named "contact allergen of the year" by the American Contact Dermatitis Society in 2012 and have since earned a spot in the baseline series of allergy testing [14].

For patients with suspected acrylic allergy, patch testing is traditionally performed by applying adhesive allergen patches to the upper back and assessing subsequent skin reaction [15]. Some of the most commonly utilized acrylic allergens with documented high reactivity are 2-hydroxymethylmethacrylate (2HEMA) (0.7\%), MMA (0.4\%), ethylene glycol dimethacrylate (EGDMA) (0.4\%) [16], and acrylic acid (1\% and $0.1 \%$ petroleum) [17].

Despite the growing concern for acrylic allergies, over a million cataract surgeries are performed annually in the USA [18] with no reported allergic reactions to acrylic IOLs, including a large case study of causes of lens explantation [19]. Given that the most commonly used materials for IOL implants are acrylic (PMMA hydrophobic acrylate, and hydrophilic acrylate) [20], one would expect reports of acrylic atopy to occur, especially with the disruption of the blood-aqueous barrier during phacoemulsification. A possible reason for sustained lens biocompatibility is the absence of IOL polymer breakdown into the allergen-inducing monomers during or after lens implantation. Furthermore, the anterior chamber-associated immune deviation phenomenon observes a low rejection rate and minimal use of immunosuppressants after corneal allografts [21-23], supporting ophthalmic immune evasion. Given these reasons, we suspect that acrylic allergy is likely not an ophthalmologic concern regarding cataract surgery lens selection, and routine allergen testing is not indicated.

However, there are some instances where management of patients with a documented acrylic allergy needing IOL implantation may warrant additional evaluation, such as reassurance for legal reasons or patients' peace of mind. Some ophthalmologists have recommended a tape test in which a sample IOL is taped to the patient's arm to assess for a localized reaction. This approach does not have scientific basis and is unlikely to yield a positive result. Instead, patch testing as described above is a more appropriate method. Additionally, non-acrylic intraocular lenses may be considered in patients who are persistently hesitant with regards to their acrylic allergy. One report of a patient with a documented MMA allergy tolerated a silicone acrylic-free IOL (KS-3Ai) without any complications [24]. In addition to silicone IOL, other non-acrylic options could include Staar nanoFLEX ${ }^{\circledR}$ Collamer ${ }^{\circledR}$ C4204A or CQ2015A (Monrovia, CA, USA). Although these non-acrylic IOL options are appealing for patients concerned about an acrylic allergy, 
there are complications to consider, the most common of which is posterior capsular opacification in silicone IOLs [25].

In summary, acrylates are in a multitude of products in both the consumer and medical setting and comprise a growing portion of allergic contact dermatitis. Patients with a documented acrylic allergy seeking cataract surgery will most likely tolerate the standard of care with acrylic IOL as there is no evidence suggesting need for further allergy testing. Patients should be reassured about the complete lack of documented sensitization to acrylic IOLs. However, patch testing to a broad array of acrylates, as well as a discussion of non-acrylic IOL options, may be pursued in select patients.

\section{ACKNOWLEDGMENTS}

Special thanks to Shannon McCabe and Yasmyne Ronquillo for their assistance in editing.

Publication Originality Statement. We confirm that this publication is original.

Funding. This study was funded by an unrestricted grant from Research to Prevent Blindness (RPB), 360 Lexington Avenue, 22nd Floor New York, NY 10017, USA. No support was received for the publication of this article.

Authorship. All named authors meet the International Committee of Medical Journal Editors (ICMJE) criteria for authorship for this manuscript, take responsibility for the integrity of the work, and have given final approval to the version to be published.

Disclosures. All authors declare that they have no conflict of interest.

Compliance with Ethics Guidelines. This article is based on previously conducted studies and does not contain any studies with human participants or animals performed by any of the authors.
Data Availability. Data sharing is not applicable to this article as no datasets were generated or analyzed during the current study.

Open Access. This article is distributed under the terms of the Creative Commons Attribution-NonCommercial 4.0 International License (http://creativecommons.org/licenses/ by-nc/4.0/), which permits any noncommercial use, distribution, and reproduction in any medium, provided you give appropriate credit to the original author(s) and the source, provide a link to the Creative Commons license, and indicate if changes were made.

\section{REFERENCES}

1. Chirila TV, Constable IJ, Russo AV, Linton RG. Ridley intraocular lens revisited: chemical analysis of residuals in the original lens material. J Cataract Refract Surg. 1989;15(3):283-8. https://doi.org/10. 1016/s0886-3350(89)80085-9.

2. Ridley H. Intra-ocular acrylic lenses after cataract extraction. Lancet. 1952;1(6699):118-21. https:// doi.org/10.1016/s0140-6736(52)92426-4.

3. Hoffer KJ. The evolution of the intraocular lens. In: Cataract surgery. 3rd edn. https://doctorlib.info/ surgery/cataract/36.html. Accessed 27 May 2021.

4. Hollick EJ, Spalton DJ, Ursell PG, Pande MV. Biocompatibility of poly(methyl methacrylate), silicone, and AcrySof intraocular lenses: randomized comparison of the cellular reaction on the anterior lens surface. J Cataract Refract Surg. 1998;24(3): 361-6. https://doi.org/10.1016/s0886-

3350(98)80324-6.

5. Taylor JS. Acrylic reactions-ten-years' experience. In: Current topics in contact dermatitis. Berlin Heidelberg: Springer; 1989. p. 346-51. https://doi. org/10.1007/978-3-642-74299-6_73.

6. Mahadevia AA, Weiland D, Kvamme P, Murphy KPJ, Srinivas A, Wyse G. Polymethylmethacrylate contact dermatitis after vertebroplasty. J Vasc Interv Radiol. 2007;18(4):585. https://doi.org/10.1016/j. jvir.2007.01.026.

7. Jelen G. Acrylate, a hidden allergen of electrocardiogram electrodes. Contact Dermatitis. 2001;45(5):315-6. https://doi.org/10.1034/j.16000536.2001.450522.x. 
8. Lyons G, Nixon R. Allergic contact dermatitis to methacrylates in ECG electrode dots. Australas J Dermatol. 2013;54(1):39-40. https://doi.org/10. 1111/j.1440-0960.2012.00918.x.

9. Núñez-Acevedo B, González-Fernández MT, Juangorena MM, Vidal C. Multifunctional acrylates as possible sensitizers in electrocardiogram electrode allergy. Ann Allergy Asthma Immunol. 2013;111(1):77-8. https://doi.org/10.1016/j.anai. 2013.05.009.

10. Ozkaya E, Kavlak BP. Allergic contact dermatitis caused by self-adhesive electrocardiography electrodes: a rare case with concomitant roles of nickel and acrylates. Contact Dermatitis. 2014;70(2): 121-3. https://doi.org/10.1111/cod.12146.

11. Stingeni L, Cerulli E, Spalletti A, et al. The role of acrylic acid impurity as a sensitizing component in electrocardiogram electrodes. Contact Dermatitis. 2015;73(1):44-8. https://doi.org/10.1111/cod. 12357.

12. Hansel K, Foti C, Nettis E, et al. Acrylate and methacrylate allergy: when is patch testing with acrylic acid recommended? Contact Dermatitis. 2020;82(4):231-3. https://doi.org/10.1111/cod. 13440 .

13. Goon AT-J, Bruze M, Zimerson E, Goh C-L, SooQuee Koh D, Isaksson M. Screening for acrylate/ methacrylate allergy in the baseline series: our experience in Sweden and Singapore. Contact Dermatitis. 2008;59(5):307-13. https://doi.org/10. 1111/j.1600-0536.2008.01440.x.

14. Sauder MB, Pratt MD. Acrylate systemic contact dermatitis. Dermatitis. 2015;26(5):235-8. https:// doi.org/10.1097/DER.0000000000000136.

15. Foti C, Lopalco A, Stingeni L, et al. Contact allergy to electrocardiogram electrodes caused by acrylic acid without sensitivity to methacrylates and ethyl cyanoacrylate. Contact Dermatitis. 2018;79(2): 118-21. https://doi.org/10.1111/cod.13015.

16. Rolls S, Rajan S, Shah A, et al. (Meth)acrylate allergy: frequently missed? $\mathrm{Br} \mathrm{J}$ Dermatol. 2018;178(4):980-1. https://doi.org/10.1111/bjd. 16402 .
17. Bruze M, Mowitz M, Zimerson E, et al. No contact allergy to acrylic acid and methacrylic acid in routinely tested dermatitis patients. Contact Dermatitis. 2017;76(2):116-8. https://doi.org/10.1111/cod. 12627.

18. Pershing S, Lum F, Hsu S, et al. Endophthalmitis after cataract surgery in the United States: a report from the intelligent research in sight registry, 2013-2017. Ophthalmology. 2020;127(2):151-8. https://doi.org/10.1016/j.ophtha.2019.08.026.

19. Goemaere J, Trigaux C, Denissen L, et al. Fifteen years of IOL exchange: indications, outcomes, and complications. J Cataract Refract Surg. 2020;46(12): 1596-603. https://doi.org/10.1097/j.jcrs. 0000000000000349.

20. Bellucci R. An introduction to intraocular lenses: material, optics, haptics, design and aberration. In: Cataract, vol. 3. S. Karger AG; 2013. p. 38-55. https://doi.org/10.1159/000350902.

21. Borrás T, Gabelt BT, Klintworth GK, Peterson JC, Kaufman PL. Non-invasive observation of repeated adenoviral GFP gene delivery to the anterior segment of the monkey eye in vivo. J Gene Med. 2001;3(5):437-49. https://doi.org/10.1002/jgm. 210.

22. Eichhorn M, Horneber M, Streilein JW, LutjenDrecoll E. Anterior chamber-associated immune deviation elicited via primate eyes. Invest Ophthalmol Vis Sci. 1993;34(10):2926-30.

23. Li Z, Peng G, Li C. The role of spleen in induction and maintenance of anterior chamber-associated immune deviation in different species of animals. Yan Ke Xue Bao. 1999;15(4):221-4, 237.

24. Severinsen MA, Sommerlund M, Naeser K. Management of a cataract patient with known allergy to methyl methacrylate. JCRS Online Case Rep. 2014;2(3):68-70. https://doi.org/10.1016/j.jcro. 2014.05.003.

25. Awasthi N, Guo S, Wagner BJ. Posterior capsular opacification: a problem reduced but not yet eradicated. Arch Ophthalmol. 2009;127(4):555-62. https://doi.org/10.1001/archophthalmol.2009.3. 